\title{
Hofballet og barokke passioner
}

\author{
af Monna Dithmer
}

At dykke ned i arkiverne med skildringer af barokkens dans, er på mange planer et forunderligt møde. Man konfronteres med en dans, der, som indbegrebet af et radikalt anderledes menneskesyn og verdensbillede, slår en med sin fremmedhed og skærper sansen for, hvad vi normalt forstår ved dans. Den barokke dans udgør et markant skæringspunkt i dansens og kroppens kulturhistorie. Her udformes det grundlag, som den vestlige scenedans (i første omgang balletten) udvikler sig fra. Her dannes det individ, der sidenhen skal bære en moderne Oplysningsepokes rationelle antræk.

Denne eksemplariske status gælder primært for hofballetten, den del af barokdansen, der udspandt sig $\mathrm{i}$ aristokratiets gyldne sale. Med udspring i de italienske og franske renaissancehoffer breder hofballetten sig til hele Europa i løbet af det 16. og 17. århundrede. Som førende dansenation opviser Frankrig prototypen på en dans, der er centralt placeret som politisk magtmiddel, og som i sin form udkrystalliserer barokkens kosmologi, æstetik og menneskesyn.

»Alle menneskehedens problemer, alle de ulykker, der skaber historien politikernes bommerter, store kaptajners fejltagelser - de stammer allesammen fra, at folk ikke har lært at danse $\ll$.

Således ræsonnerer dansemesteren i en af Molières »comédies-ballets" som præcist udtryk for tidens syn på dansen som universalmodel for orden og harmoni i samfundet.

\section{Hoffet danser om Solen}

Umiddelbart kan hofballetten tage sig ud som den rene og skære ceremonielle pragtopvisning, fuld af barokke syn i ordets dobbelte forstand. Her kan dansen f.eks. udspille sig i et mobilt kildevæld i tre etager - med parfumeret vand strømmende i gyldne, delfinsmykkede bassiner, hvor sølvklædte najader, tritoner og havfruer poserer med guldspejle i hænderne. Et imponerende udstyrsstykke, men samtidig også en allegori, gennemvævet af mangetydig symbolik.

Både med hensyn til form og funktion er hofballetten et markant udtryk for en enevældig styreform. Ikke alene er det en dans, hvor hoffet selv træder an, men også i sin symbolik er hofballetten en storslået, majestætisk magtmanifestion af et samfundsmæssigt hierarki. Monarkens centrale, nærmest guddommeligt ophøjede position fejres ved en dans, hvori hoffets herrer og damer kredser om det lysende, royale midtpunkt. Ludvig d.14. fik ligefrem tilnavnet »Solkongen « ud fra en ballet, hvor han trådte frem som Solen og solguden Apollon - intet mindre end Europas, verdens, universets lysende kraftcentrum.

I hofballettens blomstringstid er dans langt fra et trivielt selskabsdiver- 
tissement, men et anliggende af både social, politisk og filosofisk karakter. Som imponerende demonstration af et hierarkisk samfundssystem, indgår balletten som et vigtigt politisk middel til at markere officielle begivenheder. Eksempelvis koreograferede statsmanden Richelieu (blandt mange andre balletter) »Ballet de la Prosperite des armes de France « (1641) som magtfuld manifestation af de franske triumfer over Spanien. Som det generelt var tilfældet, var balletten iscenesat i mytologisk antræk, med kæmpende guder og ridderlige helte.

Som manifestation af monarkens uforlignelighed og rigets uforgængelighed er hofballetten befolket af en broget skare, der på anskueliggørende vis kan spejle den hierarkiske lagdeling i samfundet. Således indgår ikke blot mytiske og eksotiske skabninger så som gudinder og græske helte, Nat og Dag, Ære og Ynde, varulve og hekse, men også mere "realistiske " figurer som f.eks. tiggere, zigeunere, vandbærere, bønder og bedragere. Dansens harmoni, symmetri og orden tjener som billede på, at riget $\mathrm{i}$ sin perfekte opbygning er den bedste af alle verdener.

\section{Overflod i geometrisk orden}

Det første egentlige eksempel på en hofballet er »Le Ballet Comique de la Reine « fra 1581, som blev arrangeret for at fejre Dronning Louises bryllup. I en storstilet, spektakulær iscenesættelse, med brug af både musik, drama, mime, sang, dans og akrobatik skildres dramaet om Merkurs befrielse af 14 najader fra troldkvinden Kirke. Blandt ballettens forunderligt udstafferede personager optræder bl.a. en skov på hjul garneret med skovnymfer, Merkur stiger ned fra en sky, Pallas Athene ankommer i en vogn med slangeforspand, Jupiter sender lyn fra himlen, og ud fra en lysflammende have træder intet mindre end en hjort, en hund, en elefant, en løve, en tiger, og et svin. Midt i denne mangfoldighed udfolder dansen sig imidlertid i stramme geometrisk ordnede mønstre. Koreografen Beaujoyeulx beskriver det afsluttende optrin:

»Optakten til Den Store Ballet bestod af femten passager, der var således udtænkt, at hver gang en af dem var afsluttet, drejede alle hovederne mod Kongen. Da de var kommet hen foran hans Majestæt, dansede de den Store ballet bestående af fyrre dele med geometriske figurer. Nogen placerede sig diametralt, nogen dannede en firkant, nogle en cirkel, på mange forskelligartede måder (...) Disse geometrisk udfoldede mønstre tog undertiden form af en trekant med dronningen foroven. De drejede rundt i en cirkel, vævede sig ind i en kæde og formede forskellige figurer med en samstemthed og præcision, som forbløffede de tilstedeværende.« (B. Beaujoyeulx $\mathrm{i} » \mathrm{~A}$ History of Ballet and Dance«s. 44-45).

Ballettens geometriske figurer (der var beregnet til at blive set ovenfra), føjer sig ind $i$ hofballettens allegoriske natur. Firkanter, diamanter, ovaler, trekanter har hver deres symbolværdi. Eksempelvis betyder trekanter »Retfærdighed «, en firkant indeni en firkant betyder »Dydigt Forehavende«, og tre cirkler inden i hinanden betyder »Fuldkommen Sandhed «. I sin geometriske konstruktion er hofballetten ikke blot en afspejling af samfundets opbygning, men også af naturens og 
universets orden. For samtiden menes geometrien at være et direkte udtryk for universets guddommelige orden. Dansens linjer og proportioner optræder som minutiøse aftryk af det overordnede makrokosmos. Ligesom planeterne kredser omkring solen, danser Nationen om den store Natur. Bag ballettens glitrende overflademangfoldighed hersker evige, guddommelige naturlove. Med dens stramme geometriske mønstre, komplekse figurationer og myldrende detaljerigdom, er hofballetten et prægtigt billede på, at enhver ting på forunderlig vis har sin plads i universet.

\section{At traede dansen med anstand}

Hofballettens vidtforgrenede symbolfunktion og centrale position i samfundslivet bereder ikke blot vejen for

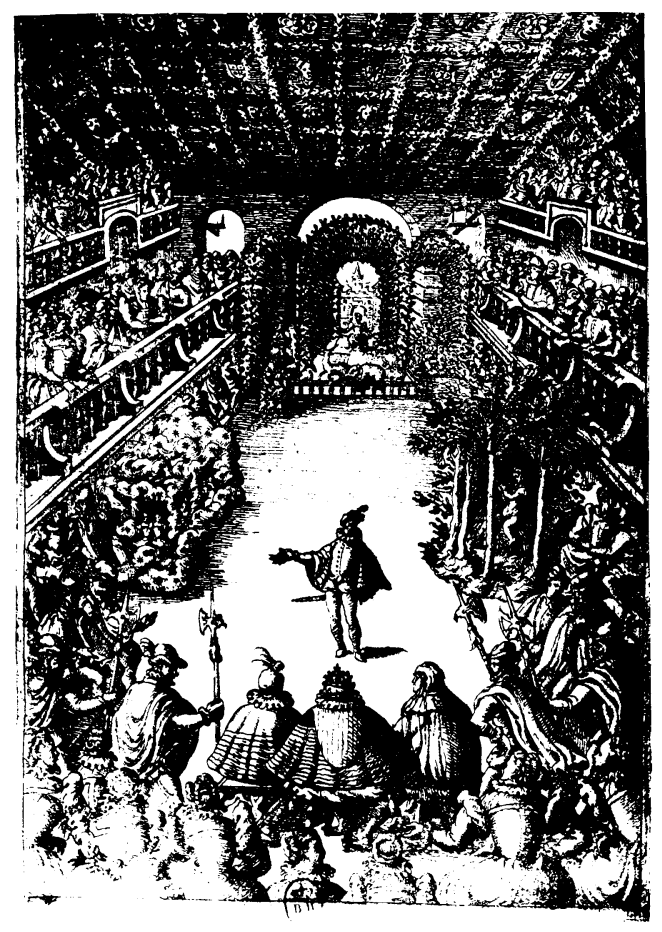

utallige dansemestres glorværdige karriere indenfor koreografi og instruktion, men giver også anledning til en lang række lærde, vejledende skrifter om balletternes form og indhold.

I sin lille afhandling »Hvordan man komponerer en ballet med held « (1641) fremhæver Saint-Hubert, at variation og afveksling er vigtig i det foreskrevne antal »entrees « - i alt 30 stk. - en kongelig ballet bør indeholde. Komiske, groteske numre bør veksle med alvorsfulde, sk $\emptyset$ nhedss $\emptyset$ gende numre. Endvidere skal der være et overordnet, samlende emne for balletten, helst af ny og overraskende karakter. Hvad angår dansernes $\emptyset$ nske om at fremvise deres færdigheder, påpeger Saint-Hubert dog, at de ikke må fortabe sig $\mathrm{i}$ virtuose hop og indviklede trin, og derved glemme deres repræsentative symbolfunktion. Danserne optræder som typer, med en nøje afstemt betydning i forhold til ballettens betydningsunivers. Både bevægelserne, kostumerne og de insignier (en stav, en slange, et kors, en sky etc.) de bærer med sig, er udtryk for deres allegoriske funktion $\mathrm{i}$ forestillingen.

Med hensyn til hofballettens forskellige former for danse og bevægelsesmønstre, er der ikke så meget at hente i danseskrifterne. Men bevægelsesrepertoiret stammer i vid udstrækning fra de danse, der allerede var i brug ved hoffet. Det gælder både de mere adstadige, poserende danse, så som den elegante menuet og den påfugleagtige pavane, men også de lidt mere viltre med hop og drejninger, så som galliard og lavolta. Hvad angår de akrobatiske optrin hentede man professionelle dansere udefra, således at »høj《 og »lav« reelt blandede sig i dansens samfundspy- 
ramide. Generelt er dansen dog præget af reservation, elegance og anstand. Ligesom i musikken er der rum til improvisationer, men samtidig kræves præcision og akkuratesse $\mathrm{i}$ forhold til den overordnede struktur. På raffineret vis virker dansen stram og flydende på en og samme gang.

Bevægelserne er nøje koordinerede ud fra fastlagte regelsæt. Håndleddenes bevægelser skal svare til ankelens, og albuens bevægelser skal svare til knæets etc. Endvidere er bevægelserne også styret ud fra de forskellige kropsdeles symbolværdi, f.eks. starter man ofte med venstre fod, fordi den hører hjertet til. Tager man også den foreskrevne lethed og svævende elegance i betragtning, er der ikke mulighed for de store bevægelsesudsving. Ikke mindst når man tænker på de begrænsninger, kostumerne sætter i deres omfang, bredde og tyngde (samt tilbeh $\varnothing$ ret af parykker, masker, hatte og rekvisitter). Her var mændene i deres kortere skørter noget fordelagtigere stillet end kvinderne, der frem for spring og indviklede trin, primært førte sig frem i mere reserveret, yndefuld stil. Ofte var det dog mænd, der dansede kvinderollerne, Ludvig d. 13. excellerede eksempelvis i de kvindelige partier. Også i forbindelse med kønnets masker satte samtiden stor pris på illusionen og forblændelsens kunst.

\section{Det iscenesatte blandvark}

En stor del af hofballettens fascination beror på dens evne til at skabe forunderlige, $\varnothing$ jenblændende optrin. Jo mere overdådige tableauer, uds øgte mønstre, pompøse kostumer og virtuose dansere, jo tættere er man på det eftertragtede »théâtre du merveilleux«. Ifølge dette vidunderideal skal balletten overvælde publikum som et glitrende drømmesyn fra en anden verden. Alt, der skinner, er oplagt gods for balletten: silkestoffer, ædle metaller, spejle, levende lys samt fyrværkeri. De overdådige kostumer samt maskerne (der primært tjener anonymitetens formål) understreger vægtningen af skinnet og overfladen. Til iværksættelse af fortryllelsen, hører nødvendigvis også en storslået scenografi, fyldt med udsøgte raffinementer - ikke mindst en righoldig beholdning af scene-maskineri. Alskens hejseapparater, drejemaskiner og automatinstallationer sørger for at få guder til at stige ned på jorden, kameler til at vandre, vandfald til at strømme, og skyer til at regne med blomster.

Barokdansens æstetik hylder form, stil og overflade som sublim betydningsmæssig essens. Ting er, hvad de fremtræder som. Fremtrædelsesformerne bliver dyrket til det yderste som indbegrebet af det sublime, magiske og fantastiske. Det er den store iscenesættelses tidsalder - således som Ludvig d. 14. forbilledligt illustrerer det i sine offentlige morgentoiletter og masseceremonier med håndspålæggelser i tusindvis.

\section{Når kroppen adles}

Som led i den totale iscenesættelse af barokkens menneske indgår dans som centralt middel til at fremelske en sand adelsmand. I forlængelse af renæssancens høviske forskrifter er idealet det alsidigt dannede, sofistikerede individ, der med største elegance kan bevæge sig mellem at recitere poesi, føre en filosofisk diskurs, st øde med kården, 
svinge sig op på hesten eller træde dansen. Overalt gælder de samme aristokratiske idealer om finsleben ånd, elegance $\mathrm{i}$ adfærd og alsidig kunstfærdighed. At kunne føre sig med stil er adelsmærket. Udførlige anvisninger forefindes for alle aspekter af nobel adfærd: hvordan man skal svinge hatten til hilsen, gøre passende reverenser, stille sig i positur etc.

Der er intet hierarki eller nogen skarp opdeling mellem de forskelllige dannelsesdiscipliner, som hofetiketten foreskriver. Fægteren, rytteren, danseren og filosoffen er en og samme figur - og dansen optræder som forbindelsesled mellem dem alle. Fægtekunsten er eksempelvis baseret på de samme principper, som gør sig gældende for dansen: en rank holdning, udaddrejede fødder, balanceevne, hurtige vægtoverføringer og fejende armbevægelser. Dansen kan også foregå på hesteryg, de såkaldte »hesteballetter « var yderst populære. Som videreførsel af middelalderens ringridning drejede det sig om, at heste og ryttere skulle danne symmetriske bevægelsesm $\varnothing$ nstre i et rytmisk, afstemt forløb.

Denne kunstfærdige hestedressur kan i $\varnothing$ vrigt ses som et præcist billede på den grad af bemestring, som det aristokratiske barokmenneske har opnået overfor kroppen. Som mageløst civilisationskreatur er kroppen blevet tæmmet og forædlet til en kunstgenstand, hvori naturen kommer til syne i rendyrket, ophøjet form.

Med den kultiverede harmoni mellem krop og ånd betragter barokmennesket sig selv som det gennemført sofistikerede individ - en unik kulmination på århundreders civilisationsproces.

\section{Passioner i krop og sjael}

Som dannelsesmiddel placerer dansen sig ikke blot centralt i forhold til det politiske og kulturelle liv, men også i religiøs forstand. Hofballetten er gennemvævet af den kristne religion, i teori så vel som i praksis. De primære danseteoretikere i hofballettens blomstringstid er eksempelvis alle kirkens mænd. På mange læreanstalter er det præster, der står for danseundervisningen, ligesom de også laver koreografier. Mens kirken gennem århundreder primært har set det som sin opgave at bekæmpe dans som ren og skær hedenskab, træder dansen nu frem i tydelig katolsk iklædning (især jesuitterne, der i Frankrig spiller en fremtrædende rolle i modreformationen, gør sig stærkt gældende på danseområdet). Hofballetten udformes indirekte som led i opgøret med protestantismen. Dens pragt, allegoriske betydning og spektakulære formationer er ensbetydende med en hævdelse af den katolske kirkes mystik, ritualer og processioner, overfor de protestantiske reformatorers billedstormeri og nøgterne, didaktiske bestræbelser.

I hofballetten videreføres således en kristen (katolsk) symbolik, ikke mindst hvad angår synet på kroppen. Det er som videreudvikling heraf, at den klassiske ballet udvikles i Frankrig i det 18. århundrede og breder sig til resten af Europa. Scenedansen i Vesten er i fundamental forstand en dans om den syndefaldne krop og sjælens nådegave. Barokdansen betragtes som et middel til at opløfte ånden mod Gud, som er »den store mester i den ballet, som alle skabninger danser i trin og bevægelser« (Père Marin Mer- 
senne $\mathrm{i}$ »Harmonie universelle«, 1636). Dansen afspejler himmellegemernes og hele universets dans, og har til opgave at genskabe den himmelske harmoni på jorden. Harmoniforestillingen kendes også fra middelalder og renæssance, men i den barokke dans er den kendetegnet ved en større grad af spænding. Balancen og overensstemmelsen mellem himmel og jord, mellem sjæl og krop er ikke længere noget givet, men noget der skal tilkæmpes.

Dette kampaspekt hænger sammen med den ændrede opfattelse af sjælen, som efterhånden har sat sig igennem. Frem for at være evig og uforanderlig, hævet over de menneskelige emotioner, betragtes sjælen som bevægelig, omskiftelig og i bestandig affekt. Den katolske modreformation stadfæster $\mathrm{i}$ midten af det 16 . århundrede denne opfattelse af sjælen som en passioneret størrelse. Kroppen hævdes at være »en fyldt krop«, dvs. hensat i en permanent tilstand af »affectus« som forankring for sjælens omtumlede bevægelser.

Det er i lyset af denne sjælekval, at dansen får sin store betydning som den kunstart, der primært er i stand til at udtrykke sjælens bevægelser: »Dansen kan udtrykkke tingenes natur og sjælens vante gang, som ikke kan gribes af forstanden på anden vis end gennem disse dansende bevægelser.« (C.F. Ménestrier i »Le Ballets Anciens et Modernes«, 1652 s 14)

Dansen anses for at være et gunstigt midddel til at skabe harmoni og balance - idet der samtidig er mulighed for at udtrykke den underliggende, ulmende lidenskab. Som »udtryk for sjælens lidenskaber « sikrer dansen en udveksling mellem indre og ydre, en afbalanceret kamp mellem kødet og ånden.
Dansen letter kroppen for dens syndefaldstyngde.

Her kan kroppen tillades at udtrykke sig, men på afbalanceret, indirekte vis. Der er tale om en lyst og en kødelighed, der udtrykkes som en diskret erotik, kendetegnet ved antydningsvise berøringer, nøje afmålte rytmer og glidende bevægelser.

Den barokke dans er et perfekt udtryk for, at kød og ånd ikke (længere) lader sig skille fuldstændig ad, idet sjælen i og med dens kropslige forankring også er blevet bytte for emotionerne. Den syndefaldne krop fremtræder $» r e-$ habiliteret « i dansen. Kødets lyster og sjælens passioner finder her et sublimeret og renset udtryk - men immervæk et udtryk. I dansen kan mennesket fremstå som »affectus«, uden at havne i kødets mørke og tage skade på sin sjæl. Denne sejr over syndefaldskroppen og den uovervindelige afstand mellem krop og sjæl fejres i hofballetten med dens glorværdige fremstillinger af barokkens menneske.

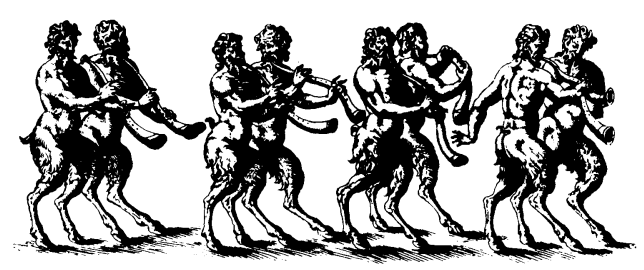

\section{Barokt efterspil}

Ser man på den franske dansescene af $\mathrm{i}$ dag, er det bemærkelsesværdigt, i hvor høj grad hofballetten inden for det sidste årti har fået en renæssance - ikke blot i form af omfattende rekonstruktioner, men også i form af direkte ny- 
skabelser, inspireret af barokdansens grundformer. Dette kan umiddelbart ses i sammenhæng med den nye dans' karakteristiske afsøgning af sine historiske rødder. Ligeledes er barokdansens illusionsæstetik også på linje med den tidsaktuelle, postmodernistiske dyrkelse af blændværk og overflade som betydningernes essens. Men som kroppens og sjælens passionsdans byder hofballetten sig også til i dag, i kraft af en langt mere nuanceret opfat- telse end den sort-hvide krop/sjæl-dikotomi, som en stor del af kroppens kulturhistorie bygger på. Den raffinerende sensualitet, diskrete erotik og finslebne åndfuldhed, der ligger i det barokke kropsbillede, tages frem som et forfriskende modstykke til de "frigjorte kroppe«, som ellers har været enerådende på forførelsens marked. I den forstand kan barokdansen som kroppens forunderlige teater også i dag forblænde et publikum.

\section{Litteratur}

Arbeau, Thoinot „Orchesography» (1588) 1976, Paris.

Bland, Alexander $» A$ History of Ballet and Dance«, 1976, London.

Bourcier, Poul "Histoire de la danse en Occident«, 1978, Paris.

Christout »Le ballet de cour de Louis xiv«, $\mathrm{Pa}-$ ris, 1967.
Cohen, Selma Jeanne »Dance as a Theatre Art«, 1974, New York.

MacGowan, Margaret »L'Art du Ballet de cour «, (1938) 1963, Paris.

Zur Lippe, Rudolf "Naturbeherrschung am Menschen«, 1974, Frankfurt am Main. 